\title{
Effect of Food Intake on Protein Quality Measured in Chicks by Traditional or Biochemical Methods
}

\author{
Diamela Carías, Anna M Cioccia and Patricio Hevia* \\ Laboratorio de Nutrición, Universidad Simón Bolívar, Apartado Postal 89000, Caracas, Venezuela
}

(Received 4 March 1998; accepted 19 March 1998)

\begin{abstract}
Previous studies have shown that the activities of the hepatic enzymes xanthine dehydrogenase and nucleoside phosphorylase, as well as the uric acid excreted, can be used to determine the quality of the protein consumed in chickens, in a short time and using a small amount of the test protein. A common observation in protein quality evaluation is that the food intake of the control animals is considerably greater than that observed in those receiving proteins of low quality. Since this can affect the results, this study measured the quality of garbanzo bean and black bean proteins in chickens fed these beans ad libitum, feeding the bean diets at the level observed in the controls (soy protein + methionine) by enteral intubation or pair feeding the controls with the amount of food consumed by the chickens receiving the bean diets. In every case, protein quality was determined by protein efficiency ratio, net protein utilisation or the biochemical methods used in this study. The results showed that, when fed ad libitum, the animals assigned to the bean diets exhibited a lower food intake than the controls but, by tube feeding, food intake was made equal in both groups. Equal consumption, between these groups, was also obtained by reducing the amount of food offered to the controls to the levels measured in the groups assigned to the bean diets (pair feeding). These feeding strategies had a marked effect on growth, carcass protein content, protein catabolism and also in the results of protein quality. Thus, the control whose intake was reduced grew less, accumulated less protein in tissues and catabolised more of the protein consumed than the control fed ad libitum. In contrast, the chickens assigned to the bean diets, but whose food intake was increased by tube feeding, grew better, accumulated more protein in tissues and catabolised less protein. In general, the results of these experiments confirm the effectiveness of the biochemical methods for estimating protein quality and indicate that the protein quality of both garbanzo beans and black beans increased when it was measured at a food intake equivalent to that measured in the control animals. Since the overall purpose of this study was to evaluate techniques for protein quality determination meant to be applicable to humans nutrition rather than poultry nutrition, single proteins were used instead of combinations of proteins. (C) 1998 Society of Chemical Industry.
\end{abstract}

J Sci Food Agric 78, 479-485 (1998)

Key words: protein quality; food intake; purine enzymes; uric acid

\footnotetext{
* To whom correspondence should be addressed.

Contract/grant sponsor: CONICIT.

Contract/grant number: S1-1242.
} 


\section{INTRODUCTION}

The evaluation of protein quality is a key factor in the search for new protein sources as well as in the development of food proteins. Accordingly, methods have been proposed which allow the determination of protein quality in a very short time, using a small amount of the test protein. These methods are based on the determination of either the hepatic activities of the purine enzymes xanthine dehydrogenase (EC 1.2.1.37) or nucleoside phosphorylase (EC 2.4.2.1) or the uric acid excretion in chickens receiving the test protein in the diet ad libitum for a few days (1-3 days) (Hevia and Clifford 1977; Millán et al 1984a; Hevia et al 1990; Vit et al 1993a). These methods show a very good correlation with the traditional methods for determining protein quality such as protein efficiency ratio or net protein utilisation, which are sensitive to small changes in the quality of the dietary protein and produce results in a very short time (Millán et al 1984b; Casas et al 1987; Vit et al 1993b). An additional advantage of this methodology is that the protein is tested in vivo and, thus, it is affected by the effects that food processing or toxic factors which occur naturally in foods may have on the availability of proteins (Henley and Kuster 1994; Young and Pellet 1994; Sarwar 1997). This is overlooked by the in vitro methods, such as the chemical score, unless it is corrected by the digestibility of the test protein run in vivo (Henley and Kuster 1994; Young and Pellet 1994; Carías et al 1995).

A common observation during the evaluation of protein quality in vivo is a voluntary reduction in food intake in the animals assigned to the test protein when the quality of this protein is lower than the control protein. This may affect the results of the test, since, in this case, the protein consumed is partially utilised as a source of energy and less is incorporated in new protein tissues. As a result, the quality of this protein may be underestimated (Harper 1958; Kino and Okumara 1986a, 1988; Muramatsu 1990).

These observations lead to the conclusion that, to accurately measure the quality of a protein, the food intake of the experimental group and the control group should be similar.

One way of achieving similar food intakes in the experimental and control groups is to include a group consuming the control protein but pair-fed with the test protein group. Pereira et al (1990), however, indicated that severely restricting food intake in chickens fed soybean protein was associated with a significant reduction in its protein quality measured by PER, NPU and also the methods used here. They suggested that the reduction in protein quality measured at low food intakes resulted from both the utilisation of the dietary soybean protein as a source of energy and also to the anxiety that the food restriction imposed on the experimental animals.
Another way of achieving similar food intakes among the control and the test groups is by intubating enterally the test proteins to the level observed in the control group fed ad libitum (Kino and Okumara 1986a,b, 1988). This procedure has also been used by Kraus et al (1997) to study the effect of antioxidants in zinc-deficient rats.

In harmony with the previous arguments, the objective of the present study was to assess the effect of food intake in the evaluation of protein quality in chicks. For this purpose, the quality of black beans and garbanzo beans were evaluated by both methods used for this purpose as well as by markers of protein catabolism. The hepatic purine enzymes, xanthine dehydrogenase and nucleoside phosphorylase, as well as the uric acid excreted by the chicks, were measured as indicators of protein catabolism. The chicks consumed these beans as their only protein source, and, in all cases, the results were compared with those obtained from a control group fed soybean protein with added methionine. All proteins were offered ad libitum, pair-fed and tube-fed. Since the overall purpose of these studies was to evaluate techniques for protein quality determination, applicable to humans nutrition rather than poultry nutrition, single proteins were used instead of combinations of proteins.

\section{EXPERIMENTAL}

\section{Sample preparation}

Approximately $5 \mathrm{~kg}$ of either black beans (Phaseolus vulgaris) or garbanzo beans (Cicer arietinum) were soaked in water overnight and cooked under pressure $\left(121^{\circ} \mathrm{C}\right)$ for $20 \mathrm{~min}$. The grains were then dried at $70^{\circ} \mathrm{C}$ for $48 \mathrm{~h}$ and ground to a fine powder in a laboratory mill.

\section{Experimental animals and conditioning}

One-day-old male Warren chicks, obtained from a commercial hatchery, were conditioned for 7 days with the soybean protein + methionine diet shown in Table 1 . At the beginning of the conditioning period, seven chicks were kept in the same cage and were then progressively separated so that, at the 7th day, there was one chick per cage. During the conditioning as well as the experimental periods, the wire-bottom stainless-steel cages had a permanently lit $60-\mathrm{W}$ bulb for heating. Food was offered to the chicks from $7.00 \mathrm{AM}$ to $7.00 \mathrm{PM}$, and water was offered all day.

\section{Experiment 1}

Thirty-six conditioned chicks were randomly distributed into six groups. Three of these groups received the 
TABLE 1

Composition $\left(\mathrm{g} \mathrm{kg}^{-1}\right)$ of the control (soy + methionine) and the black bean and garbanzo bean diets used in experiments 1 and 2 , respectively ${ }^{a}$

\begin{tabular}{|c|c|c|c|}
\hline \multirow[t]{2}{*}{ Added ingredient } & \multirow[t]{2}{*}{ Control } & \multicolumn{2}{|c|}{ Experimental } \\
\hline & & $\begin{array}{l}\text { Black } \\
\text { beans }\end{array}$ & $\begin{array}{c}\text { Garbanzo } \\
\text { beans }\end{array}$ \\
\hline Soybean protein ${ }^{b}$ & $177 \cdot 7$ & 一 & 一 \\
\hline Experimental proteins ${ }^{c}$ & - & 600 & $694 \cdot 4$ \\
\hline Corn oil & 40 & 40 & 40 \\
\hline L-Methionine & $3 \cdot 5$ & - & - \\
\hline Cellulose & 30 & 30 & 30 \\
\hline Mineral mix ${ }^{a}$ & 35 & 35 & 35 \\
\hline Vitamin $\operatorname{mix}^{a}$ & 20 & 20 & 20 \\
\hline $\mathrm{CaHPO}_{4} \cdot 2 \mathrm{H}_{2} \mathrm{O}$ & 36 & 36 & 36 \\
\hline Corn starch & $657 \cdot 8$ & $239 \cdot 0$ & $144 \cdot 6$ \\
\hline
\end{tabular}

${ }^{a}$ The diets as well as the mixtures of minerals and vitamins were prepared according to Peterson et al (1971).

${ }^{b}$ SUPRO $760^{\mathrm{TM}}$, Protein Technologies International (St Louis, MO, USA) with $84 \cdot 4 \%$ protein.

${ }^{c}$ The black bean and garbanzo bean flours used in the experimental diets had 25 and $21.6 \%$ protein, respectively. Prepared as indicated in the table, the three diets had $150 \mathrm{~g}$ protein $\mathrm{kg}^{-1}$ diet.

soybean protein + methionine diet (control) and two the black bean diet shown in Table 1. The sixth group received a protein-free diet. From the groups assigned to the control diet, one was fed ad libitum, one was tube-fed with the same amount of food consumed by the ad libitum group and one was offered the same amount of diet consumed by the black bean group fed ad libitum (pair-fed). From the groups assigned to the black bean diet, one was fed this diet ad libitum and the other was tube-fed the same diet but to the level of intake observed in the group receiving the control diet ad libitum. In order to tube-feed the amount of food consumed by the control animals, the diet was suspended in water (1 part diet and 2 parts water) and the chicks were given this suspension orally, four times a day. The chicks were intubated with a 5-7-cm-long, 3-mm-diameter soft plastic tubing hooked to a $10-\mathrm{ml}$ syringe. The intubation of the chicks was very simple to perform and it was not stressful to the birds. The tube was inserted in the beak and gently pushed $3-4 \mathrm{~cm}$ down the oesophagus. The birds rapidly adapted to this kind of feeding, and, after a few days, they spontaneously looked for the tube. The food consumption of all birds was registered daily, and excreta were collected during the last 3 days of the 7-day experiment.

At the end of the experiment, the chicks were killed by cervical dislocation, the livers were dissected, frozen with liquid nitrogen and kept at $-30^{\circ} \mathrm{C}$ until their purine enzymes activities were analysed. The carcasses and excreta were dried at $70^{\circ} \mathrm{C}$, ground and kept at $-30^{\circ} \mathrm{C}$ for the determination of body composition and total nitrogen and uric acid content.

\section{Experiment 2}

This experiment was identical to experiment 1, but garbanzo beans were used instead of black beans.

The protocol for these experiments fulfilled the Universidad Simón Bolívar regulations for laboratory animal care and use for research. These regulations agree with the principles set forth in the Guide for the Care and Use of Laboratory Animals (NRC 1996).

\section{Methods}

The nitrogen content of the diets, excreta and carcasses was determined by the method described by Hevia and Cioccia (1988) and Cioccia et al (1995), and body fat and water were determined by the methods of Blight and Dyer (1958) and the AOAC (1990), respectively. The purine enzymes were extracted from the liver as described by Hevia and Clifford (1977). The activities of the enzymes xanthine dehydrogenase and nucleoside phosphorylase were measured as described by Tramper and Angelino (1979) and Hevia and Clifford (1978), respectively. Uric acid was extracted from the excreta as described by Hevia and Clifford (1977) and determined by the methods of Liddle et al (1959).

The protein efficiency ratios (PERs) were determined from the total protein consumed and the growth registered during the whole study as described by the AOAC (1990), and the net protein utilisation (NPU) of the same proteins was calculated from the nitrogen consumed and excreted by the chicks fed the protein diets and the protein-free diet as recommended by Bender and Miller (1953). The conditions of the NPU assay were essentially those described by NRC (1963), but chicks were used instead of rats.

The results were analysed using one-way analysis of variance and correlation (Steel and Torrie 1988), and the means were compared using the least significant difference (LSD). For these analyses, the statistical package for the social sciences SPSSPC V 6.0 from SpSS (Chicago, IL, USA) was used.

\section{RESULTS}

The results show that the chicks assigned to the control diet, fed ad libitum or tube-fed, behaved similarly in terms of food intake, growth and body composition in both experiments (Table 2 and 3). In addition, the same tables show that the quality of the control diet (PER or NPU) fed ad libitum was identical to that observed 
TABLE 2

Growth, food intake, protein quality and body composition of chicks fed the control diet ad libitum, tube-fed or pair-fed or the black bean diet ad libitum or tube-fed during 7 days in experiment $1^{a}$

\begin{tabular}{|c|c|c|c|c|c|}
\hline & \multicolumn{3}{|c|}{ Soybean protein + methionine (control) } & \multicolumn{2}{|c|}{ Black bean } \\
\hline & Ad libitum $^{b}$ & Tube-fed $d^{c}$ & Pair-fed $d^{d}$ & Ad libitum $^{b}$ & Tube-fed ${ }^{e}$ \\
\hline Growth $\left({\left.\mathrm{g} 7 \mathrm{~d}^{-1}\right)}\right.$ & $37 \cdot 03 \pm 1 \cdot 56 \mathrm{a}$ & $37 \cdot 88 \pm 0 \cdot 45 a$ & $26 \cdot 95 \pm 0.55 b$ & $17 \cdot 40 \pm 0 \cdot 42 c$ & $22 \cdot 48 \pm 0.79 d$ \\
\hline 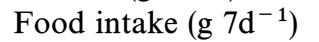 & $94 \cdot 63 \pm 2 \cdot 26 a$ & $93 \cdot 50 \pm 0 \cdot 00 \mathrm{a}$ & $69 \cdot 78 \pm 0.28 b$ & $70 \cdot 73 \pm 1 \cdot 18 b$ & $93 \cdot 50 \pm 0 \cdot 00 \mathrm{a}$ \\
\hline PER & $2.60 \pm 0.03 a$ & $2.69 \pm 0.03 a$ & $2.57 \pm 0.06 a$ & $1.61 \pm 0.01 b$ & $1.58 \pm 0.06 b$ \\
\hline NPU & $81 \cdot 73 \pm 140 \mathrm{a}$ & $86 \cdot 66 \pm 0.78 a$ & $75 \cdot 72 \pm 2 \cdot 80 b$ & $48 \cdot 43 \pm 2 \cdot 14 \mathrm{c}$ & $62 \cdot 36 \pm 2 \cdot 10 \mathrm{~d}$ \\
\hline Total body protein $(\mathrm{g})$ & $15 \cdot 55 \pm 0 \cdot 37 a$ & $15 \cdot 80 \pm 0.09 a$ & $11.93 \pm 0.28 b$ & $8 \cdot 56 \pm 0 \cdot 28 \mathrm{c}$ & $11 \cdot 02 \pm 0 \cdot 11 b$ \\
\hline Total body fat (g) & $5 \cdot 53 \pm 0 \cdot 23 a$ & $5 \cdot 91 \pm 0 \cdot 16 \mathrm{a}$ & $4 \cdot 85 \pm 0 \cdot 21 b c$ & $4 \cdot 45 \pm 0 \cdot 10 \mathrm{c}$ & $4.97 \pm 0 \cdot 15 b$ \\
\hline
\end{tabular}

${ }^{a}$ Entries are means \pm standard error of 6 chicks. In the same row, means with different letters are statistically different according to least significant difference at $5 \%$.

${ }^{b}$ The chicks ate as much as they wanted.

${ }^{c}$ The chicks received by intubation the amount of food consumed by the control group fed ad libitum.

${ }^{d}$ The chicks were offered the control diet but at the level of intake registered in the black bean group fed ad libitum.

${ }^{e}$ The chicks received by intubation the bean diet. The amount of diet given was fixed by the consumption measured in the control chicks fed ad libitum.

when this diet was tube-fed. Similar results were obtained when the markers of protein catabolism were compared between the groups which received the control diet either ad libitum or tube-fed. Thus, the hepatic activities of the enzymes xanthine dehydrogenase and nucleoside phosphorylase or the excretion of uric acid measured in the chicks fed the control diet ad libitum were equal to those observed in the chicks which received the same diet by intubation both in experiments 1 and 2 (Tables 3 and 4).

In contrast with the previous observations, reducing the consumption of the control diet by offering this chicks the amount of food consumed by the chicks assigned to the black bean or the garbanzo bean diets in experiments 1 and 2 (pair-fed groups), respectively, resulted in a substantial reduction in growth and a lower body protein and fat content (Tables 2 and 3). In addition, these chicks, per gram of nitrogen consumed, had higher activities of the purine enzymes xanthine dehydrogenase and nucleoside phosphorylase in the liver and also excreted more uric acid, indicating that they were catabolising more of the protein consumed in both experiments (Tables 4 and 5). These observations coincide with a lower utilisation of the control protein in this pair-fed group, as shown by a reduction of the NPU value of this protein (Tables 2 and 3). This indicates that, per gram of the control protein consumed, the chicks fed this protein ad libitum or tube-fed retained more than those consuming at a lower level of intake.

Tables 2 and 3 show that the chicks fed the black bean or the garbanzo bean diets ad libitum had a lower food intake, grew less and had lower body protein and fat than those assigned to the control protein fed ad libitum or tube-fed. At the same time, the data showed (Tables 4 and 5) that the hepaic purine enzymes in these chicks were substantially more active and that they excreted more uric acid than the groups receiving the

TABLE 3

Growth, protein quality and body composition of chicks fed the control diet ad libitum, tube-fed or pair-fed or the garbanzo bean diet ad libitum or tube-fed during 7 days in experiments $2^{a}$

\begin{tabular}{|c|c|c|c|c|c|}
\hline & \multicolumn{3}{|c|}{ Soybean protein + methionine (control) } & \multicolumn{2}{|c|}{ Garbanzo bean } \\
\hline & Ad libitum & Tube-fed & Pair-fed & Ad libitum & Tube-fed \\
\hline Growth $\left({\left.\mathrm{g} 7 \mathrm{~d}^{-1}\right)}\right.$ & $33 \cdot 17 \pm 1 \cdot 28 \mathrm{a}$ & $32 \cdot 91 \pm 0 \cdot 48 a$ & $23 \cdot 57 \pm 0 \cdot 83 b$ & $16 \cdot 16 \pm 0 \cdot 66 c$ & $20 \cdot 52 \pm 0 \cdot 62 d$ \\
\hline 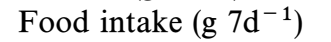 & $90 \cdot 68 \pm 1 \cdot 42 a$ & $89 \cdot 74 \pm 0 \cdot 00 \mathrm{a}$ & $70 \cdot 60 \pm 0 \cdot 31 b$ & $71 \cdot 52 \pm 1 \cdot 69 b$ & $89 \cdot 74 \pm 0 \cdot 00 \mathrm{a}$ \\
\hline PER & $2 \cdot 59 \pm 0 \cdot 07 a$ & $2 \cdot 60 \pm 0 \cdot 04 a$ & $2 \cdot 37 \pm 0 \cdot 08 \mathrm{a}$ & $1 \cdot 58 \pm 0 \cdot 03 b$ & $1 \cdot 60 \pm 0 \cdot 05 b$ \\
\hline NPU & $82.72 \pm 0.89 a$ & $82 \cdot 19 \pm 1 \cdot 42 a$ & $76 \cdot 75 \pm 1 \cdot 50 b$ & $59 \cdot 85 \pm 1.03 c$ & $67 \cdot 77 \pm 1 \cdot 39 d$ \\
\hline Total body protein (g) & $14 \cdot 63 \pm 0 \cdot 21 a$ & $14 \cdot 55 \pm 0 \cdot 19 a$ & $11 \cdot 07 \pm 0 \cdot 16 b$ & $8 \cdot 30 \pm 0 \cdot 43 c$ & $10 \cdot 20 \pm 0 \cdot 32 b$ \\
\hline Total body fat (g) & $6 \cdot 07 \pm 0 \cdot 26 a$ & $6 \cdot 06 \pm 0 \cdot 17 a$ & $5 \cdot 17 \pm 0 \cdot 16 b$ & $4 \cdot 95 \pm 0 \cdot 20 b$ & $5 \cdot 44 \pm 0 \cdot 16 b$ \\
\hline
\end{tabular}

\footnotetext{
${ }^{a}$ For details, see footnotes of Table 2.
} 
TABLE 4

Hepatic xanthine dehydrogenase and nucleoside phosphorylase and total uric acid excreted in chicks fed the control diet ad libitum, tube-fed or pair-fed or the black bean diet ad libitum or tube-fed during 7 days in experiment $1^{a}$

\begin{tabular}{|c|c|c|c|c|c|}
\hline & \multicolumn{3}{|c|}{ Soybean protein + methionine (control) } & \multicolumn{2}{|c|}{ Black bean } \\
\hline & Ad libitum & Tube-fed & Pair-fed & Ad libitum & Tube-fed \\
\hline $\begin{array}{l}\text { Xanthine dehydrogenase } \\
\quad\left(\mu \text { mol-NADH } \mathrm{g}^{-1} \text { liver } \mathrm{h}^{-1}\right)\end{array}$ & $37 \cdot 82 \pm 3 \cdot 83 a$ & $40 \cdot 78 \pm 4 \cdot 00 \mathrm{ab}$ & $53 \cdot 96 \pm 3 \cdot 39 b$ & $123 \cdot 49 \pm 7 \cdot 93 c$ & $84 \cdot 62 \pm 5 \cdot 96 \mathrm{~d}$ \\
\hline $\begin{array}{l}\text { Nucleoside phosphorylase } \\
\quad\left(\mu \text { mol-uric-acid } \mathrm{g}^{-1} \text { liver } \mathrm{h}^{-1}\right)\end{array}$ & $154 \cdot 75 \pm 8 \cdot 21 \mathrm{a}$ & $134 \cdot 08 \pm 5 \cdot 88 \mathrm{a}$ & $232 \cdot 47 \pm 10 \cdot 59 b$ & $311 \cdot 72 \pm 6 \cdot 85 b$ & $216 \cdot 53 \pm 6 \cdot 81 b$ \\
\hline $\begin{array}{l}\text { Total uric acid excreted } \\
\qquad\left({\left.\mathrm{g} 3 \mathrm{~d}^{-1}\right)}^{-1}\right.\end{array}$ & $372 \cdot 69 \pm 22 \cdot 26 a$ & $304 \cdot 11 \pm 13 \cdot 62 a$ & $477 \cdot 28 \pm 31 \cdot 34 b$ & $777 \cdot 33 \pm 32 \cdot 28 c$ & $461 \cdot 88 \pm 32 \cdot 26 b$ \\
\hline
\end{tabular}

${ }^{a}$ See Table 2 for details. The enzyme activities as well as the excretion of uric acid are expressed per gram of nitrogen consumed.

control diet ad libitum or tube-fed. This indicates that the chicks consuming the beans catabolised more protein than the controls. These observations agree with the lower protein quality (PER and NPU) of the beans shown in Tables 2 and 3 and indicate that the markers of protein catabolism were capable of detecting the differences in protein quality between the control diet and the experimental diets.

The data in Table 2 and 3 also indicate that increasing the consumption of the black beans or the garbanzo bean diets by intubating them to the level of consumption seen in the controls resulted in a stimulation of growth in chicks which had more body protein. The same tables show that the NPU value of both the black beans and the garbanzo beans tube-fed were higher than the NPU of the same proteins fed ad libitum. This improvement in the results of the protein quality assays for the protein present in black beans and garbanzo beans due to a higher diet consumption also produced an effect on the markers of protein catabolism studied here. Thus, the chicks whose consumption of the black bean or garbanzo bean diets was increased by tube feeding had, per unit of protein consumed, a lower hepatic activity of both xanthine dehydrogenase and nucleoside phosphorylase and excreted less uric acid than the chickens receiving the same diets ad libitum (Tables 4 and 5). This indicates that increasing food intake caused a reduction in the catabolism of the protein consumed, which improved the outcome of the protein quality evaluation assays.

The results of a correlation analysis between the hepatic activities of both purine enzymes or the excretion of uric acid on the NPU values of all the proteins included in the study fed ad libitum, tube-fed or pair-fed, showed high $(r>0.9)$ and negative correlation coefficients in both experiments. This is due to the fact that, in all situations in which the retention (NPU) of the protein consumed increased or decreased, protein catabolism was affected in the opposite direction. The correlation obtained with PER were lower, since this indicator of protein quality, which is based on growth, was less affected by the feeding strategies used here, probably because growth requires a longer time to respond.

\section{DISCUSSION}

The objective of these experiments was to study the effect of food intake on the determination of protein quality of a control protein (soybean + methionine) and two experimental proteins (black bean and garbanzo beans) by the traditional methods based on growth

TABLE 5

Hepatic xanthine dehydrogenase and nucleoside phosphorylase and total uric acid excreted in chicks fed the control diet ad libitum, tube-fed or pair-fed or the garbanzo bean diet ad libitum or tube-fed during 7 days in experiment $2^{a}$

\begin{tabular}{lcccccr}
\hline & \multicolumn{3}{c}{ Soybean protein + methionine (control) } & & \multicolumn{2}{c}{ Garbanzo bean } \\
\cline { 2 - 4 } \cline { 6 - 7 } & Ad libitum & Tube-fed & Pair-fed & & Ad libitum & Tube-fed \\
\hline Xanthine dehydrogenase & $50 \cdot 38 \pm 4 \cdot 45 \mathrm{ab}$ & $42 \cdot 79 \pm 3 \cdot 01 \mathrm{a}$ & $66 \cdot 05 \pm 4 \cdot 48 \mathrm{~b}$ & & $132 \cdot 49 \pm 8 \cdot 45 \mathrm{c}$ & $85 \cdot 85 \pm 3 \cdot 24 \mathrm{~d}$ \\
Nucleoside phosphorilase & $144 \cdot 67 \pm 6 \cdot 62 \mathrm{a}$ & $135 \cdot 05 \pm 7 \cdot 04 \mathrm{a}$ & $216 \cdot 06 \pm 6 \cdot 69 \mathrm{~b}$ & & $301 \cdot 65 \pm 9 \cdot 04 \mathrm{c}$ & $201 \cdot 13 \pm 8 \cdot 05 \mathrm{~b}$ \\
Total uric acid excreted & $350 \cdot 72 \pm 19 \cdot 13 \mathrm{a}$ & $348 \cdot 08 \pm 14 \cdot 74 \mathrm{a}$ & $455 \cdot 01 \pm 11 \cdot 64 \mathrm{~b}$ & & $583 \cdot 35 \pm 23 \cdot 16 \mathrm{c}$ & $409 \cdot 85 \pm 7 \cdot 97 \mathrm{~d}$ \\
\hline
\end{tabular}

\footnotetext{
${ }^{a}$ See Table 2 and 4 for details.
} 
(PER) or protein retention (NPU) and also by biochemical markers of protein catabolism such as the hepatic activities of the purine enzymes xanthine dehydrogenase and nucleoside phosphorylase or the excretion of uric acid. The control diet was offered ad libitum and pair-fed with the experimental diets, while the experimental diets were offered ad libitum and also tubefed to the level seen in the control diet. These strategies were successful, since, by restricting the food offered to the control animals and tube feeding the experimental diets, groups of chicks consumed, the control and the experimental diets at identical levels.

The results showed that the quality of the proteins, measured either by protein retention or protein catabolism, was significantly affected by food intake. Thus, the retention of the soybean + methionine protein decreased and the catabolism of this protein increased when its consumption was restricted. Moreover, the retention of the experimental proteins increased and their catabolism decreased when their intake was elevated by tube feeding. All these observations agreed with the results of body composition which showed less body protein and fat in the chicks consuming the control diet at restricted intakes and more body protein in the chicks consuming the experimental diets at intakes greater than their ad libitum consumption. These data show that, by increasing the consumption of diets which are not well accepted by the experimental animals, the utilisation of its protein and, therefore, the results of the protein quality assays can be substantially increased. This increment can also be achieved by restricting the consumption of the control diet by pair feeding.

The previous arguments point to the convenience of measuring protein quality having similar intakes for the control and the experimental animals using pair feeding or tube feeding. Although both methods require extra effort, the authors favour tube feeding because this method does not require a pair-fed control for each experimental protein. It does not negatively affect growth, body composition or protein metabolism, as shown here by the results of the tube-fed control group and because tube feeding was associated with a real improvement in the quality of the experimental protein. Food restriction, in contrast, improved the quality of the experimental proteins just by offering a more favourable comparison with a control protein that was poorly utilised.

The increment in protein quality for both the black beans and the garbanzo beans as a result of modifying food intake may seem unrealistic because the chicks did not reject voluntarily the control diet nor consumed voluntarily the beans at the levels achieved by tube feeding. This information, however, is interesting, since it represents the quality of the studied proteins in conditions where the energy requirements are met. This condition may apply in real life to human or animals consuming mixed diets.
In general, these experiments show that the biochemical methods based on protein catabolism for estimating protein quality are useful and also that the nutritional value of a protein is affected by food intake.

\section{ACKNOWLEDGEMENTS}

The study was funded by CONICIT (Grant S1-1242) and Decanato de Investigación y Desarrollo Universidad Simón Bolívar.

\section{REFERENCES}

AOAC 1990 Official Methods of Analysis (15th edn) Association of Official and Analytical Chemists, Washington, DC, USA.

Bender A E, Miller W J 1953 A new brief method of estimating net protein value. Biochem $J 53$ 7-16.

Blight E G, Dyer W J 1958 A rapid method of total lipid extraction and purification. Can J Biochem Physiol 37 911920.

Carías D, Cioccia A M, Hevia P 1995 Grado de concordancia entre la digestibilidad de proteínas animales y vegetales medidas in vivo e in vitro y su efecto sobre el Cómputo Químico. Latinoam Nutr Arch 45 111-116.

Casas C E, Millán N, Brito O, Hevia P 1987 Oxypurines and purine enzymes as fast markers of dietary protein quality in growing chickens. Nutr Rep Int 35 837-845.

Cioccia A M, Gonzalez E. Pérez M, MoraJ A, Romer H, Molina E, Hevia P 1995 Application of a colorimetric method to the determination of the protein content of commercial foods, mixed human diets and nitrogen losses in infantile diarrhoea. Intern J Food Sci Nutr 46 21-29.

Harper H A 1958 Balance and imbalance of amino acid. Ann Acad Sci 69 1025-1033.

Henley E C, Kuster J M 1994 Protein quality evaluation by protein digestibility-corrected amino acid scoring. Food Technol 48 74-77.

Hevia P, Cioccia A M 1988 Application of a colorimetric method to the determination of nitrogen in nutritional studies with rats and humans. Nutr Rep Int 38 1129-1136.

Hevia P, Clifford A J 1977 Protein intake, uric acid metabolism and protein efficiency ratio in growing chicks. $J$ Nutr 107 959-963.

Hevia P, Clifford A J 1978 Protein intake, hepatic purine enzymes levels and uric acid production in growing chicks. $J$ Nutr 108 46-54.

Hevia P, Brito O, Cioccia A M 1990 A fast biochemical method for determining protein quality. Italian $J$ Food Sci Special Issue 242-245.

Kino K, Okumara J 1986a Improvement of body weight and nitrogen balance of chicks fed histidine-free of lysine-free diets with suplementation of graded levels of sulfurcontaining amino acid. Poultry Sci 65 1736-1740.

Kino K, Okumara J 1986b The effect of single essential amino acid deprivation on chick growth and nitrogen and energy balances at ad libitum and equalized-food intakes. Poultry Sci 65, 1728-1735.

Kino K, Okumara J 1988 Evaluation of nutritional quality for amino acid mixtures deficient in some essential amino acids in chicks under an equalized-feeding condition. Nutr Rep Int 38 239-247. 
Kraus A, Roth H-P, Kirchgessner M 1997 Supplementation with vitamin $\mathrm{C}$, vitamin $\mathrm{E}$ or $\beta$-carotene influences osmotic fragility and oxidation damage of erythrocytes of zinc deficient rats. J Nutr 127 1290-1296.

Liddle L, Seegmiller J E, Laster L 1959 The enzymatic spectrophotometric method for the determination of uric acid. J Lab Clin Med 54 903-913.

Millán N, Brito O, Hevia P 1984a Calidad nutricional de las proteínas de soya y caseína dañadas térmicamente, por un método enzimático. Arch Latinoam Nutr 34 708-713.

Millán N, Brito O, Hevia P 1984b Purine enzyme and uric acid excretion as indicators of protein quality in chickens fed soy-gelatin mixtures. Nutr Rep Int 30 1367-1376.

Muramatsu T 1990 Nutrition and whole body protein turnover in the chicken in relation to mammalian species. Nutr Res Rev 3 211-228.

NRC 1963 Evaluation of Protein Quality. National Research Council, National Academy of Sciences, Washington, DC, USA.

NRC 1996 Guide for the Care and Use of Laboratory Animals. National Research Council, National Academy Press, Washington, DC, USA.

Pereira M, Cioccia A M, Brito O, Hevia P 1990 Protein quality determined at reduced food intakes. Italian $J$ Food Sci Special Issue 264-267.
Peterson D W, Hamilton W H, Lilyblade A L 1971 Hereditary susceptibility of dietary induction of gout in selected lines of chickens. J Nutr 101 347-354.

Sarwar G 1997 The protein digestibility-corrected amino acid score method overestimates the quality of proteins supplemented with limiting amino acids in rats. J Nutr 1271290 1296.

Steel R G D, Torrie J H 1988 Bioestadistica Principios Y Procedimientos McGraw-Hill, Primera Edición en Español, Mexico.

Tramper J, Angelino S 1979 Kinetics and stability of immobilized chicken liver xanthine dehydrogenase. Biotech Bioeng 1 1767.

Vit P, Cioccia A M, Brito O, Hevia P 1993a Hepatic purine enzymes and uric acid excretion as indicators of protein quality in chickens fed graded L-lysine diets. J Sci Food Agric 62 369-374.

Vit P, Cioccia A M, Hevia P 1993b Tiempo mínimo para detectar calidad proteica usando indicadores del catabolismo proteico en pollos. Arch Latinoam Nutr 43286 293.

Young V R, Pellet P L 1994 Plant proteins in relation to human protein and amino acid nutrition. Am J Clin Nutr 59 suppl 1203S-1212S. 